\title{
The historical DeVelopment of Presbyterian ordination POLITY AS BACKGROUND TO THE GAY AND LESBIAN ORDINATION debate in the Presbyterian Church (U.S.A.)
}

Author:

Roché F. Vermaak ${ }^{1}$

\section{Affiliation:}

1Presbyterian Church

(U.S.A.), Brentwood

Presbyterian Church, Los

Angeles, USA

\section{Correspondence to:}

Roché Vermaak

email:

vermaak@verizon.net

Postal address:

2512, 28th Street, Apt 101, Santa Monica, CA, 90405, USA

\section{Keywords:}

Adopting Act of 1729; 'five points or fundamentals' of 1910; gay and lesbian; General Assembly; General Assembly Permanent Judicial Commission ordination and/or installation; Presbyterian Church; Special Commission of 1925

\section{Dates:}

Received: 09 July 2009 Accepted: 26 May 2010 Published: 23 Sept. 2010

How to cite this article: Vermaak, R.F., 2010, 'The historical development of Presbyterian ordination polity as background to the gay and lesbian ordination debate in the Presbyterian Church (U.S.A.)', Verbum et Ecclesia 31(1), Art. \#50, 5 pages. DOI: 10.4102/ve.v31i1.50

This article is available at: http://www.ve.org.za
(C) 2010. The Authors. Licensee: OpenJournals Publishing. This work is licensed under the Creative Commons Attribution License.

\section{ABSTRACT}

The United Presbyterian Church in the U.S.A. and the Presbyterian Church in the U.S. united in 1983 to form the Presbyterian Church (U.S.A.). Since 1978, these three denominations have been involved in an ongoing debate regarding same-gender relationships. Subsequently, General Assemblies and General Assembly Permanent Judicial Commissions (GAPJC) - the highest denominational court - have formed a polity regarding the election and ordination and / or installation of gays and lesbians as officers, i.e. deacons, elders, and ministers of the Word and Sacrament, as well as same-gender blessings and marriages. This first of three papers will focus on the historical development of Presbyterian ordination polity with emphasis on specific markers such as the Adopting Act of 1729 with its emphasis on scrupling and essentials, the five fundamentals of 1910 and the Special Commission of 1925 regarding subscription, G-6.0106b Book of Order, and relevant GAPJC rulings.

\section{INTRODUCTION}

The United Presbyterian Church in the U.S.A. (UPCUSA) and the Presbyterian Church in the U.S. (PCUS), which united in 1983 to form the Presbyterian Church (U.S.A.) (PC(USA)), have since 1978 formulated specific polity regarding the ordination and/or installation of gays and lesbians as officers, i.e. deacons, elders and ministers of the Word and Sacrament, and same-gender blessings and marriages. This paper serves as a background to the gay and lesbian ordination debate by tracing the historical development of the Presbyterian ordination polity through decisions made by the Synod of the Presbyterian Church in the United States of America (PCUSA) in 1729 regarding essentials and scruples, and the 1910, 1926 and 1927 General Assemblies of the PCUSA regarding subscription. The subsequent predominance of polity, rather than theological discourse, to solve theological issues laid the historical foundation for the same-gender ordination and marriage debates and the development of the accompanying polity since 1978. This paper and the following two papers are evidence of this development. Thus, I will trace the development of polity without discussing the theology of samegender ordination or marriages.

\section{PRESBYTERIAN GOVERNANCE AND THE ELECTION OF OFFICERS}

The Presbyterian governing and election system serves as backdrop for the ordination and/or installation debate regarding officers-elect who have been elected or called to a specific office. The PC(USA) has four governing bodies, namely the session, presbytery, synod, and General Assembly, which are governed by both elders and ministers (G-9.0101 Book of Order). The session consists of a set amount of elders (an equal amount of elders in three staggered classes of three-year terms) and the minister(s), and governs the local congregation. Every session sends an allotted amount of delegates or presbyters, consisting of the minister(s) and elders, to represent the congregation in the local presbytery. Any elder, whether active or inactive from the session, can be a commissioner (delegate) to the local presbytery, synod, or the General Assembly (G-14.0210 Book of Order), participates and votes with the same authority as ministers, and is eligible for any higher office (G-6.0302 Book of Order). Honourably retired ministers, as well as ordained ministers serving in other capacities outside of congregations - ministers-at-large and validated ministers - hold their membership in the local presbytery.

Typically, every congregation has a Nominating Committee, elected by the congregation during a congregational meeting, to nominate deacons and elders from the active membership on behalf of the congregation. Additionally, the congregation can nominate deacons and elders, and active members can self-nominate (G-14.0232 Book of Order). The session does not vote on the slate from the Nominating Committee; the congregation votes on the slate during a congregational meeting. Once the congregation votes to elect the nominated deacons and elders, the session trains and examines the newly elected officers. Upon session's approval, a date is set during a worship service for ordination and/or installation. If the session does not approve the examination of an elected officer, it reports the decision to the Nominating Committee, which will bring a new nomination to a congregational meeting (G-14.0240 Book of Order).

Becoming a minister of the Word and Sacrament in the PC(USA) involves a two-stage process. The presbytery enrolls a person, on recommendation from their session, to become an inquirer and later a candidate. On completion of studies, examinations, internship, etc., the status of a candidate becomes 'certified ready [for ministry] for examination, pending a call' (G-14.0450 Book of Order).

Ministers (or teaching elders) are called by the Pastor Nominating Committee (PNC), a committee appointed by the session and voted on by the congregation (G-14.0531 Book of Order). The PNC 
conducts the search for a minister, which includes candidates (for ministry) and ministers, extends a call on behalf of the congregation and reports it to the session, which does not vote on the candidate but sets a date for a congregational meeting to vote and approve the call. The PNC informs the Stated Clerk of the Presbytery, and the Committee on Ministry (COM) typically meets with the candidate and makes a recommendation to the presbytery to examine and/or approve the minister at the next presbytery meeting (G-14.0532 Book of Order). Once the presbytery approves the call, it approves a committee to ordain and/or install the minister. Thus, a ministerial call is approved by both the congregation and the presbytery. Ministers who serve congregations are also part of the session, with vote, but their membership belongs with the local presbytery (G-11.0401a Book of Order)

Ordination and/or installation of the officers-elect occurs during a congregational worship service. Once the candidates have answered the eight constitutional questions in the affirmative (W-4.4003a-i Book of Order), they are ordained for life to that specific office. Ordination is when a person is ordained and installed to an office through kneeling (if they are able), prayer and the laying on of hands; installation is when a previously ordained officer is installed to the same office again, with prayer, but without the laying on of hands (W-4.4004b Book of Order). In summary, a session ordains and/or installs deacons and elders; a presbytery ordains and/or installs ministers. The presbytery, acting as the corporate bishop, has oversight over every session and all officers under its jurisdiction, including the ordination and/or installation of all officers.

\section{THE HISTORICAL DEVELOPMENT OF PRESBYTERIAN ORDINATION POLITY}

Presbyterians trace their polity roots regarding ordination back to 1729 and the modernist-fundamentalist controversy in the early twentieth century.

\section{The Adopting Act of 1729}

Two groups of Presbyterians existed in the PCUSA in the 1700s, namely the Scotch-Irish group (not Scots or Scottish), and the English-Welsh group (Rogers 1995:27) or New England group (Balmer \& Fitzmier 1994:25). In the 1720s, the New Castle Presbytery (Scotch-Irish) favoured subscription to the Westminster Standards or Westminster Confession of Faith which would ensure correct theology, while the New England Presbytery (English-Welsh) had a less rigorous position on subscription (Balmer \& Fitzmier 1994:25-26, Loetscher 1983:64). At the 1729 Synod meeting - it acted as a General Assembly both sides had lined up their arguments, but they reached a compromise with the Adopting Act of 1729, which was written mostly by Rev. J. Dickinson from the New England Presbytery (Balmer \& Fitzmier 1994:26-27).

In the Adopting Act of 1729, the Synod declared:

And do therefore agree that all the ministers of the Synod, or that shall hereafter be admitted into this Synod, shall declare their agreement in, and approbation of, the Confession of Faith, with the Larger and Shorter Catechisms of the Assembly of Divines at Westminster, as being in all the essential and necessary articles, good forms of sound words and systems of Christian doctrine; and do also adopt the said Confession and Catechisms as the confession of our Faith. And we do also agree, that all the presbyteries within our bounds shall always take care not to admit any candidate of the ministry into the exercise of the sacred function, unless he declares his agreement in opinion with all the essential and necessary articles of said Confession, either by subscribing the said Confession of Faith and Catechisms, or by a verbal declaration of their assent thereto, as such minister or candidate for the ministry shall have any scruple with respect to any article or articles of said Confession or Catechisms, he shall at the time of his making said declaration declare his sentiments to the presbytery or Synod, who shall, notwithstanding, admit him to the exercise of the ministry within our bounds and to ministerial communion if the Synod or presbytery shall judge his scruple or mistake to be only about articles not essential and necessary in doctrine, worship or government. But if the Synod or presbytery shall judge such ministers or candidates erroneous in essential and necessary articles of faith, the Synod or presbytery shall declare them uncapable of communion with them. And the Synod do solemnly agree, that none of us will traduce or use any opprobrious terms of those that differ from us in these extraessential and not-necessary points of doctrine, but treat them with the same friendship, kindness, and brotherly love, as if they had not differed from us in such sentiments.

Thus, though the Adopting Act of 1729 required all ministers to subscribe to 'the essential and necessary doctrines of said Confession', it did not specify exactly what the essential and necessary articles were. In fact, the Presbyterian Church has never defined what these essentials are, except from 1910-1927 (see below). Also, any minister could, in good conscience, declare a scruple or disagreement to the presbytery or synod, in which they declared how they departed from the Westminster Standards. If the problem was not regarding an essential or necessary article, the presbytery had to admit the scrupulous minister. In other words, the Adopting Act of 1729 was both flexible and ambiguous. It confirmed that some beliefs and practices were indispensible, but that 'differences always have existed and have been allowed' (PCUSA Minutes 1868:33, quoted in Coalter, Wheeler \& Wilkinson 2005:9-10).

This historical polity principle is the key to understanding the current ordination and/or installation debate: should and can gay and lesbian Christians in committed relationships be ordained and/or installed as officers or is it a violation of an essential article? Should they declare a scruple? And how should their scruple be judged? This question will be dealt with in the next article.

\section{THE 'FIVE POINTS OR FUNDAMENTALS'}

\section{OF 1910}

Several events in the PCUSA since the 1890s prefigured the events of 1910. First, conservatives reacted to Dr C.A. Briggs, who, at his inaugural address at Union Seminary in New York, The Authority of Holy Scripture, defended the supernatural inspiration of Scripture and higher criticism, which took into account the human character of the biblical writings. Briggs denied the Mosaic authorship of the Pentateuch and the unitary authorship of the book of Isaiah, as well as the inerrancy of Scripture developed by Princeton Seminary (Weston 1997:7). Second, since the 1890s, moderate Presbyterians, including Briggs, attempted to revise the Westminster Confession of Faith. After several failed attempts, the 1900 General Assembly appointed a Committee of Fifteen to recommend revisions to the Confession of Faith and, in 1903, the presbyteries approved revisions to the Westminster Confession (Balmer \& Fitzmier 1994:87). The revision opened the way for the Cumberland Presbyterian Church, with Arminian views of free will (Weston 1997:12), formed in 1810 by revivalist ministers who held looser understandings of confessional standards, to unite with the PCUSA in 1906 (Balmer \& Fitzmier 1994:61).

However, the Fundamentalists at the 1910 and 1916 General Assemblies reacted to the liberal theological tendencies of ministerial candidates (Longfield 2000:37) and set an extraconfessional doctrinal test (Rogers 1995:30). Thus, conservatives reacted to the broadening of the church by narrowing the doctrine in 1910, approving a 'five points' declaration of 'essential and necessary doctrines' that all ministerial candidates for ordination had to affirm: (1) the inerrancy of Scripture, (2) the virgin birth of Christ, (3) Christ's substitutionary atonement, (4) 
Christ's bodily resurrection and (5) the authenticity of biblical miracles (Longfield 2000:37) or Christ's miracles (Weston 1997:18). The 'five points' were reaffirmed by the 1916 and 1923 General Assemblies. By the 1920s, they were known as the 'five fundamentals' (Rogers 1995:30).

Subscription made its way into the PCUSA. Liberals fought the 'five points,' arguing that it was unconstitutional for the General Assembly to proclaim essential doctrine without the concurrence of the presbyteries (Weston 1997:19). Thus, one group emphasised the power and the authority of the General Assembly, the other the power and authority of the presbyteries, as prescribed by the Adopting Act of 1729. The implication of the 'five fundamentals' was that fundamentalists made subscription to certain theological ideas part of the polity process for ordination. The scrupling of these 'five fundamentals', which the Adopting Act of 1729 allowed, was not permitted, since they were viewed as specific essentials which could not be scrupled.

\section{The Special Commission of 1925}

Balmer \& Fitzmier (1994:58) assert that the doctrinal skirmishes since the 1880s between liberals at Union Seminary and conservatives at Princeton Seminary prefigured the fundamentalist-modernist controversy which played out in the PCUSA in the 1920s. Dr H.E. Fosdick added fuel to the debate by preaching a sermon in 1922 entitled, Shall the Fundamentalists Win? He challenged conservatives to tolerate liberals (Longfield 2000:38) and expressed doubts about the virgin birth, the supposed inerrancy of Scripture and the second coming of Christ (Balmer \& Fitzmier 1994:88). Rev. C.A. Macartney, from Philadelphia, replied with a sermon, Shall Unbelief Win? (Weston 1997:21-22). Although conservatives failed at the 1923 General Assembly to have action taken against Fosdick, the General Assembly responded by reaffirming the 'five fundamentals' of 1910 (Longfield 2000:40).

To avoid schism, the 1925 General Assembly appointed the Special Theological Commission of Fifteen, more commonly known as the Special Commission of 1925. Longfield (2000:43) believes the liberals, with their threat to leave the church, pushed the moderate conservatives to decide whether a united church or strict doctrinal orthodoxy was more important. The Commission delivered its first report in 1926, giving priority to polity, speaking up for toleration and asserting that the Presbyterian system admits diversity of view where the core of truth is identical' (quoted in Longfield 2000:89):

The principle of toleration when rightly conceived and frankly and fairly applied is as truly part of our constitution as are any of the doctrines stated in that instrument ... Toleration as a principle applicable within the Presbyterian Church refers to an attitude and a practice according to which the status of a minister or other ordained officer, is acknowledged and fellowship is extended to him, even though he may hold views that are individual on points not regarded as essential to the system of faith which the Church professes.

(quoted in Weston 1997:80)

The Special Commission of 1925 delivered its final report in 1927. The report answered the question of whether the General Assembly had any authority to declare any article to be essential and necessary. It referenced the Adopting Act of 1729, which specified that a decision as to essential and necessary articles was to be in specific cases, and not a general authority. This authority was also exercised by the presbytery and (General) Synod, which acted as a presbytery (PCUSA Minutes 1927:78). The report found that the General Assembly, as judicial court, could judge a candidate's doctrinal beliefs in a judicial action and find whether the candidate is competent for office. But, the General Assembly could not decide whether certain articles are essential and necessary to the system of doctrine contained in the Scriptures (PCUSA Minutes 1927:81).
The Special Commission of 1925 affirmed two key principles, heralding from the Adopting Act of 1729. Firstly, the right of the ordaining body to determine the fitness of a candidate was paramount. Secondly, neither the General Assembly nor the ordaining body could erect essential and necessary articles which were paraphrases of the Confessions or Scripture. The Special Commission of 1925 and the 1926 and 1927 General Assemblies, through accepting the report, reversed the decisions of the 1910, 1916, and 1923 General Assemblies of affirming the 'five points or fundamentals'.

Thus, Presbyterians in all their history, except from 1910-1927, have rejected subscription and have never defined what the essential articles are. Yet, these two issues would be at the heart of the same-gender relationship debate since the 1970s. In the absence of prescribed essentials, conservatives and centrists have advocated that only sexual activity between a married man and a woman is acceptable and that it should be part of the ordination polity since it is, in their view, an essential of Reformed faith and practice. This became on ordination standard when G-6.0106b was added to the Book of Order in 1997.

\section{G-6.0106b Book of Order}

After many years of failed attempts to add an explicit ordination standard prohibiting partnered gays and lesbians from being ordained and/or installed of officers, an ordination standard was added to the Book of Order in 1997:

$b$. Those who are called to office in the church are to lead a life in obedience to Scripture and in conformity to the historic confessional standards of the church. Among these standards is the requirement to live either in fidelity within the covenant of marriage between a man and a woman (W-4.9001), or chastity in singleness. Persons refusing to repent of any self-acknowledged practice which the confessions call sin shall not be ordained and/ or installed as deacons, elders, or ministers of the Word and Sacrament.

(G-6.0106b Book of Order)

One could argue that the current ordination standard since 1997 in G-6.0106b in the Book of Order - requiring either 'fidelity within the covenant in marriage between a man and a woman or chastity in singleness' - is nothing less than a form of subscription; one standard is elevated over all other standards for serving as officers (see Vermaak 2009, 2010).

\section{THE INTERPRETATION OF ORDINATION POLITY BY THE GENERAL ASSEMBLY PERMANENT JUDICIAL COMMISSION}

The result of the 1927 General Assembly decision to solve theological issues through polity means played itself out in several ordination cases. Earlier in the American Presbyterian governance system, the General Assembly acted as a court to issue rulings on polity issues. It has since been replaced by the General Assembly's highest court, the General Assembly Permanent Judicial Commission (GAPJC), whose rulings can only be replaced or supplemented by a future GAPJC ruling or the General Assembly. Three specific GAPJC rulings regarding ordination warrant further discussion.

\section{The 1981 Rankin Ruling}

The 1981 GAPJC of the United Presbyterian Church in the U.S.A. (UPCUSA), in Rankin, et al. v. National Capital Union Presbytery, dealt with an appeal on the installation of Rev. M.M. Kaseman, who many felt did not affirm the deity of Christ to satisfaction when the presbytery questioned him (McCarthy 1992:295). The GAPJC inherently dealt with the question about whether theological boundaries still existed, outside of which an individual might not be ordained (McCarthy 1992:296). 
The presbytery had to determine whether Kaseman had crossed these boundaries; it found he had not, and upheld his installation.

The GAPJC ruled that the Westminster confessional standards from the time of the Adopting Act of 1729 had been replaced by the Book of Order. Earlier, candidates had to 'receive and adopt' the Westminster Confession of Faith and Catechisms; now, one promised to 'be instructed ... led ... and continually guided' by The Book of Confessions. The Confessions' function to form a systematic doctrine taught by Scripture has been replaced by its function to instruct and guide the candidate as they lead God's people (UPCUSA Minutes 1981:115).

Thus, in the GAPJC's view, the new ordination and installation questions expressed and expanded the understanding of how the church viewed the function and purpose of the Confessions (UPCUSA Minutes 1981:115). Earlier, subscription to a system of doctrine was required; now, the focus was on the ability to use the Confessions, to learn and be guided by them. Earlier, empirical standards were set and the candidate's theology was judged.

Now the Constitution places the primary focus of the candidate's examination not on his or her conformity with theological prescriptions but rather on the candidate's willingness and commitment to be instructed by the Confessions of our Church and continually guided by them in leading the people of God.

(UPCUSA Minutes 1981:115)

The decision legitimised the theological pluralism in the church; there was more latitude within the confessional stance of the UPCUSA. Also, it confirmed that theoretical boundaries still existed, although the decision did not clarify what they were (McCarthy 1992:298). The result of the Rankin ruling was that the presbytery had greater responsibility in determining the candidate's commitment to be instructed by the Confessions and to use them to lead God's people. Therefore, the presbytery must have sufficient authority and '... higher judicatories should substitute their judgment only for the most extraordinary reasons' (UPCUSA Minutes 1981:115). The GAPJC noted that the Report of the Special Commission of 1925 confirmed the presbytery was '... the body qualified and constitutionally appointed to judge' candidates (UPCUSA Minutes 1981:115, see PCUSA Minutes 1927:65). The GAPJC reaffirmed the 1962 Anderson ruling that 'we reaffirm the principle that we are not to substitute our own judgment for that of the lower judicatory, which is best able to judge' (UPCUSA Minutes 1981:116, see UPCUSA Minutes 1962:324-325).

Thus, the right of the presbytery (and session), not the synod or the GAPJC, to judge candidates for ordination and/or installation was reaffirmed. The Rankin ruling reaffirmed the polity that was set by the Special Commission of 1925 and affirmed the 1962 Anderson ruling: the presbyteries (and sessions) are entrusted to examine and approve candidates. In summary, the 1981 Rankin case disapproved of prescribed interpretations of Scripture or the Constitution, affirming that Presbyterians during their entire history, except from 1910-1927, have rejected subscriptionism. However, the next paper will show how the PC(USA) has currently set one standard for ordination above all other standards.

\section{The 2008 Bush Ruling}

The 2008 GAPJC ruling, in Bush, et al. v. Presbytery of Pittsburgh pertained to G-6.0106b, which conservatives have argued is an essential of Reformed faith and practice, despite the fact that the essential articles have never been defined. The Bush ruling pointed out a huge loophole in the Authoritative Interpretation on G-6.0108 issued by the 2006 General Assembly when it adopted the 2005 Peace, Unity and Purity (PUP) Report. The recommendation of the PUP report included a rationale section, but it was not adopted by the General Assembly as part of the Authoritative Interpretation (see Vermaak 2009:344-351 for a full discussion): 'Section G-6.0108 puts "faith and polity" - belief and behavior - on an equal footing, as they were in 1729, when scruples were permitted in matters of "doctrine discipline and government" ...' (PC(USA) Minutes 2008:321).

The finally adopted Authoritative Interpretation did not equate 'polity' with 'behaviour.' Nevertheless, the church required those who are examined for ordained office to conform their actions, though not necessarily their beliefs or opinions, to certain standards, in those contexts in which the church has deemed conformity to be necessary or essential, and G-6.0106b contained such a provision which required church-wide conformity (PC(USA) Minutes 2008:321). The GAPJC confirmed the distinction between departures from standards of belief, but not from behaviour, in stating that

[t]he specific "fidelity and chastity" standard in G-6.0106b stands in contrast to the provisions of G-6.0106a ... The candidate and examining body must follow $G-6.0108$ in reaching a determination as to whether the candidate for office has departed from essentials of Reformed faith and polity, but that determination does not rest on distinguishing "belief" and "behavior," and does not permit departure from the "fidelity and chastity" requirement found in G-6.0106b.

(PC(USA) Minutes 2008:322)

Thus, departures based on conscience would not be permitted from the 'fidelity and chastity' standard of G-6.0106b. The GAPJC, in this decision, made one part of the Book of Order an essential standard and elevated sexual standards above all other required standards to hold office. It argued that 'no presbytery may grant an exception to any mandatory church wide behavioral ordination standard' and that

[t]he freedom of conscience granted in G-6.0108 allows candidates to express disagreement with the wording or meaning of provisions of the constitution [sic - capitalised], but does not permit disobedience to those behavioral standards.

(PC(USA) Minutes 2008:322)

The GAPJC elevated G-6.0106b to an essential, a mandatory standard which could not be waived or scrupled. It issued a new Authoritative Interpretation, thus setting aside the Authoritative Interpretation issued by the 2006 General Assembly. In essence, the GAPJC moved the denomination dangerously close to subscription, which Presbyterians rejected in 1927, with the Report of the Special Commission of 1925, and the 1981 Rankin ruling. In turn, the 2008 General Assembly approved another Authoritative Interpretation on G-6.0108 and replaced the 2008 Bush ruling:

The 218th General Assembly (2008) affirms the authoritative interpretation of G-6.0108 approved by the 217th General Assembly (2006). Further, the 218th General Assembly (2008), pursuant to G-13.0112, interprets the requirements of G-6.0108 to apply equally to all ordination standards of the Presbyterian Church (U.S.A.). Section G-6.0108 requires examining bodies to give prayerful and careful consideration, on an individual, caseby-case basis, to any departure from an ordination standard in matters of belief or practice that a candidate may declare during examination. However, the examining body is not required to accept a departure from standards, and cannot excuse a candidate's inability to perform the constitutional functions unique to his or her office (such as administration of the sacraments).

(PC(USA) Minutes 2008:380)

Thus, the 2008 General Assembly, and later the Office of the Stated Clerk (PC(USA) Constitutional Services 2008), clearly stated that the 2008 Bush ruling had been replaced by a new Authoritative Interpretation and that scrupling of G-6.0106b is permitted. 


\section{The 2009 Bierschwale I and II Rulings}

Despite the 2006 and 2008 Authoritative Interpretations issued by the 2006 and 2008 General Assemblies, the battle over essentials continues. The 2009 GAPJC, in Bierschwale, et al. v. Presbytery of Twin Cities Area (Bierschwale I and II), dealt with a complaint against the presbytery for restoring Dr P. Capetz to the ministry of the Word and Sacrament, after he had declared a scruple regarding G-6.0106b. The GAPJC ruled in Bierschwale I:

This Commission cannot reach the questions raised by the parties in this appeal as to the validity and effect of the 2008 Authoritative Interpretation (AI) on G-6.0108b or whether Bush has effectively been overruled by the 2008 Authoritative Interpretation.

(PC(USA) GAPJC 2009a:6)

And in Bierschwale II:

Although both parties have once again implored this Commission to rule as to the continued authority of "Bush v. Presbytery of Pittsburgh" ... in light of the 2008 Authoritative Interpretation on G-6.0108b ... this Commission declines to do so in this case.

(PC(USA) GAPJC 2009b:5)

One would assume that the GAPJC would have acknowledged that the 2008 General Assembly had replaced the 2008 GAPJC ruling in the Bush case; unfortunately, this was not the case. The next statement supplies the motivation: it also reiterated that Capetz had to abide by G-6.0106b, despite him declaring a scruple over it (PC(USA) GAPJC 2009a:6, 2009b:5). Again, the GAPJC found a loophole in the 2006 and 2008 Authoritative Interpretations of the General Assembly, which allowed a candidate to declare a scruple, but it did not specify sufficiently whether a scrupulous candidate had to abide by the specific aspect of the scruple or not. The GAPJC certainly viewed G-6.0106b as still applying to Capetz. Thus, once again, the GAPJC viewed G-6.0106b as an essential; requiring subscription to one ordination standard (see Vermaak 2009:416-419 for a full discussion). This is the first time in the entire history of the Presbyterian Church that the General Assembly and GAPJC have held opposing views and are in tension with each other.

\section{CONCLUSION}

The PC(USA) and its predecessor churches have unsuccessfully applied the 1927 decision of the PCUSA - to solve its theological issues solely through polity means - to the ordination and/or installation of partnered gay and lesbian candidates and officers. Unfortunately, as the next paper will show, theological solutions are unavailable in this polity debate regarding ordination, since polity solutions have had preference over theological interpretation. Since the 1970s the UPCUSA, PCUS and PC(USA) have all appointed special committees to study the theological implications of gay and lesbian members and officers, yet none of the reports has been adopted or become authoritative.

The result is a denomination which is worn down and fatigued after a more than 40-year polity battle. Ordination has become a case of semantics: interpretations by the General Assembly and GAPJC of what they think G-6.0106b means and whether it is an essential or not.

\section{REFERENCES}

Anderson, J.D., 1993, More Light Update, viewed 03 April 2009, from http://www.qrd.org/qrd/orgs/PLGC/newsletters/1993/04.93

Balmer, R. \& Fitzmier, J.R., 1994, The Presbyterians, Praeger Publishers, Westport.

Coalter, M.J., Wheeler, B.G. \& Wilkinson, J., 2005, Principles of polity: Their contribution to the peace, unity and purity of the Presbyterian Church, viewed 13 March 2009, from http:// www.pcusa.org/peaceunitypurity/resources/polityeng.pdf

Loetscher, L.A., 1983, A brief history of the Presbyterians: With a new chapter by George Laird Hunt, 4th edn., Westminster Press, Philadelphia.
Longfield, B.J., 2000, 'For church and country: The fundamentalist-modernist conflict in the Presbyterian Church', Journal of Presbyterian History 78(1) Spring, 35-50.

McCarthy, D.B., 1992, 'The Emerging Importance of Presbyterian Polity', in M.J. Coalter, J.M. Mulder \& L.B. Weeks (eds.), The Organizational Revolution: Presbyterians and American Denominationalism, pp. 279-306, Westminster John Knox Press, Louisville.

PCUS Minutes, Minutes of the General Assembly, Part I: Journal, Office of the General Assembly, Louisville.

PCUSA Minutes, 1927, Minutes of the General Assembly: Report of the Special Commission of 1925, [s 1], 58-86.

PCUSA, 2001, 'Report of the Special Commission of 1925 (Excerpt) 'Journal of Presbyterian History 79(1), 46-52, reprint of PCUSA Minutes 1927:77-86, viewed March 2009, from http://www.history.pcusa.org/pubs/journal/2001/2001_ spring/046052.pdf

PC(USA), 2009-2011, Book of Order. The Constitution of the Presbyterian Church (U.S.A.), Part II, Office of the General Assembly, Louisville, viewed 02 March 2010, from http://www.pcusa.org/oga/publications/2009-2011-boo.pdf

PC(USA) Constitutional Services, 2008, Advisory Opinions: Note 22 Actions of the 218th General Assembly related to G-6.0106b and G-6.0108, July, viewed 18 July 2009, from http://www.pcusa.org/constitutionalservices/ad-op/note22.htm

PC(USA) GAPJC, 2009a, Bierschwale, et al. v. Presbytery of the Twin Cities Area. Decision and Order in Remedial Case 219-08, 02 March, viewed 03 March 2009, from http://www.pcusa.org/gapjc/decisions/pjc21908.pdf

PC(USA) GAPJC, 2009b, Bierschwale, et al. v. Presbytery of the Twin Cities Area. Decision and Order in Remedial Case 219-08, 02 November, viewed 04 November 2009, from http://www.pcusa.org/gapjc/decisions/pjc21908b.pdf

PC(USA) Minutes, Minutes of the General Assembly, Part I: Journal, Office of the General Assembly, Louisville.

Rogers, J.B., 1995, Claiming the Center: Churches and Conflicting Worldviews, Westminster John Knox Press, Louisville.

The Adopting Act of 1729, viewed 13 March 2009, from http://www.pcahistory.org/documents/subscription/ adoptingact.html

UPCUSA Minutes, Minutes of the General Assembly, Part I: Journal, New York.

Vermaak, R.F., 2009, 'A historical study of the polity of the gay and lesbian ordination and/or installation, and same-gender marriage debates in the Presbyterian Church (U.S.A.) and its predecessor churches', PhD thesis, Faculty of Theology, University of Pretoria, Pretoria, viewed on 10 January 2010, from http://upetd.up.ac.za/thesis/available/etd-07042009-213526

Vermaak, R.F., [in press], 'The polity debate regarding gay and lesbian ordination and/or installation in the Presbyterian Church (U.S.A.)', Verbum et Ecclesia 31(1).

Weston, W.J., 1997, Presbyterian Pluralism: Competition in a Protestant House, University of Tennessee Press, Knoxville. 